\title{
CORRECTION
}

\section{Correction to: Lithology and fluid discrimination using rock physics-based modified upper Hashin-Shtrikman bound: an example from onshore Niger Delta Basin}

\author{
C. G. Okeugo ${ }^{1}$ (D) K. M. Onuoha ${ }^{1} \cdot$ A. C. Ekwe ${ }^{2}$
}

Published online: 30 June 2021

(c) The Author(s) 2021

\section{Correction to: \\ Journal of Petroleum Exploration and Production \\ Technology (2021) 11:569-578 \\ https://doi.org/10.1007/s13202-020-01073-2}

In the original publication of the article, Table 2 and some of the figures (Figs. 8, 9) were incorrectly published, this has been corrected in this paper.

Table 2 Average values of some of the petrophysical parameters estimated

\begin{tabular}{lllllllllll}
\hline $\begin{array}{l}\text { Well } \\
\text { name }\end{array}$ & $\begin{array}{l}\text { Gross interval } \\
(\mathrm{G})\end{array}$ & $\begin{array}{l}\text { Net reservoir } \\
(\mathrm{N})\end{array}$ & $\mathrm{N} / \mathrm{G}$ & $\begin{array}{l}\varphi_{\mathrm{av}} \\
(\mathrm{v} / \mathrm{v})\end{array}$ & $\begin{array}{l}\text { Ave. } \varphi_{\text {eff }} \\
(\mathrm{v} / \mathrm{v})\end{array}$ & $\begin{array}{l}\mathrm{Sw}_{\mathrm{av}} \\
(\mathrm{v} / \mathrm{v})\end{array}$ & $\begin{array}{l}\mathrm{Vsh}_{\mathrm{av}} \\
(\mathrm{v} / \mathrm{v})\end{array}$ & Reservoir deposits & Fluid type & Reservoir quality \\
\hline $\mathrm{A}$ & 379.50 & 243.25 & 0.64 & 0.224 & 0.219 & 0.087 & 0.020 & Distributary channel fill & Gas/brine & Very good \\
$\mathrm{C}$ & 375.30 & 285.25 & 0.76 & 0.237 & 0.199 & 0.032 & 0.160 & Shelf edge delta & $?$ & Very good \\
$\mathrm{D}$ & 528.50 & 306.50 & 0.58 & 0.233 & 0.220 & 0.112 & 0.052 & Distributary channel fill & Gas/brine & Very good \\
\hline
\end{tabular}

The original article can be found online at https://doi.org/10.1007/ s13202-020-01073-2.

C. G. Okeugo

chukwudike.okeugo@unn.edu.ng

1 Department of Geology, University of Nigeria, Nsukka, Nigeria

2 Department of Geology and Geophysics, Federal University Ndufu-Alike, Ikwo, Ebonyi, Nigeria 
Fig. 8 a AI-Porosity plot for Well D showing lithology distribution and fluid type distribution. Red colour shade $=$ gas sands, blue colour shade $=$ brine sands, and grey colour shade $=$ shale. Insert colour barGamma ray. Note The gas-brine boundary is the modified upper Hashin-Shtrikman bound line. b AI-Porosity plot for Well A showing lithology distribution and fluid type distribution. Red colour shade $=$ gas sands, blue colour shade $=$ brine sands, and grey colour shade $=$ shale. Insert colour bar-Gamma ray. Note The gas-brine boundary is the modified upper Hashin-Shtrikman bound line. c AI-Porosity plot for Well C showing lithology distribution and fluid type distribution. Red colour shade $=$ gas sands, blue colour shade $=$ brine sands, and grey colour shade $=$ shale . Insert colour bar-Gamma ray. Note The gas-brine boundary is the Hashin-Shtrikman bound line (a)

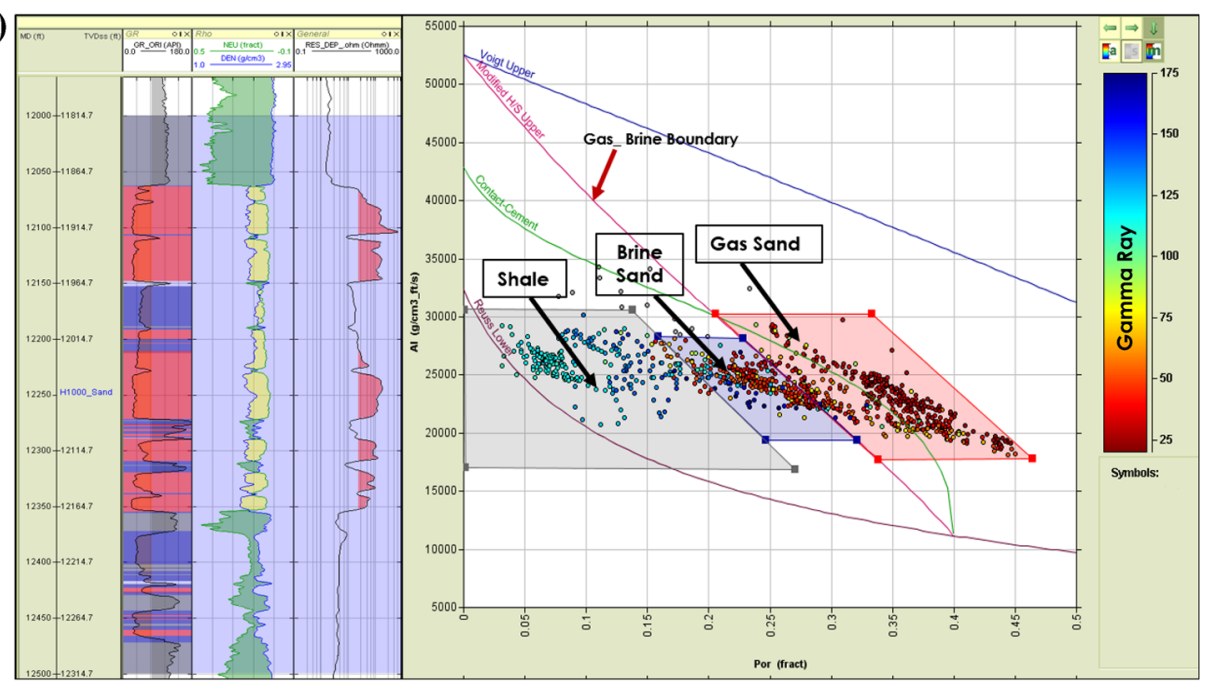

(b)

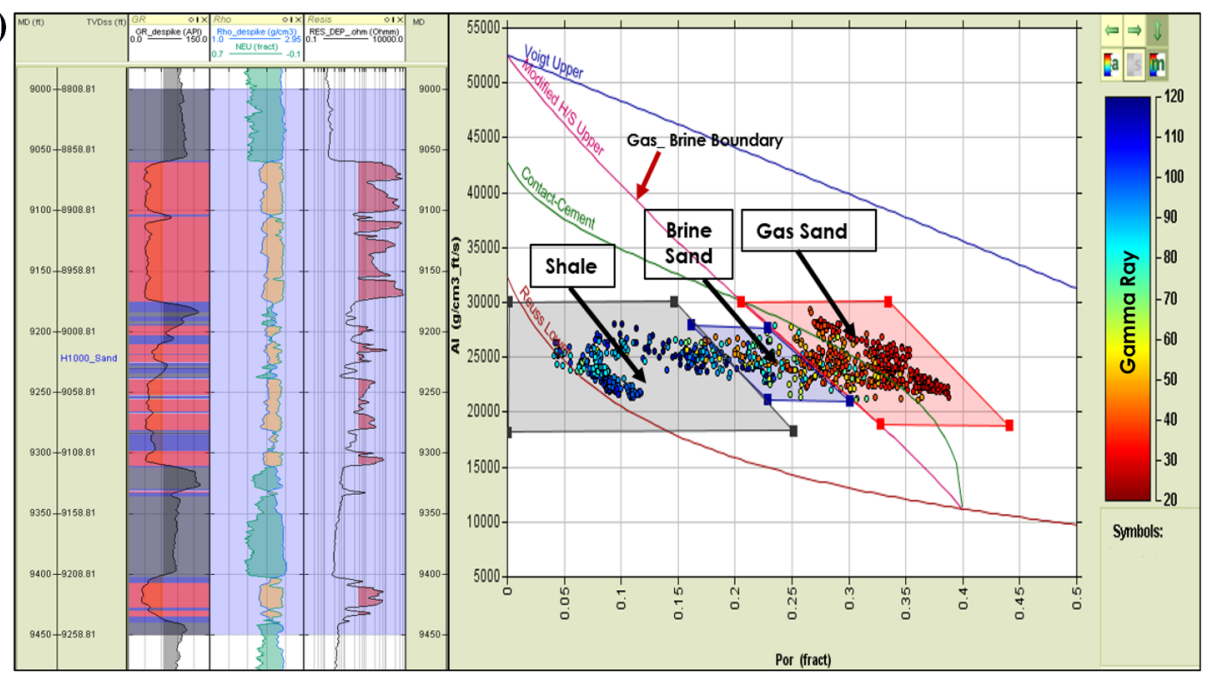

(c)

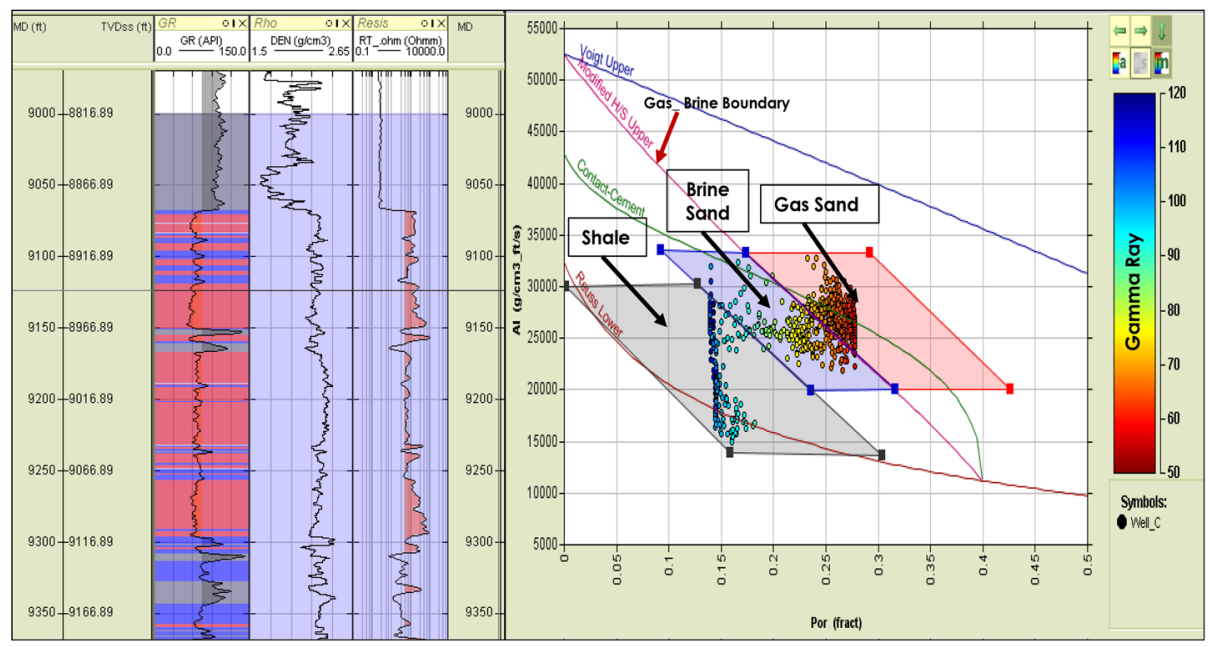


Fig. 9 A conceptual rock physics template model applicable for the study area showing lithologies and fluids as well as porosity trend lines

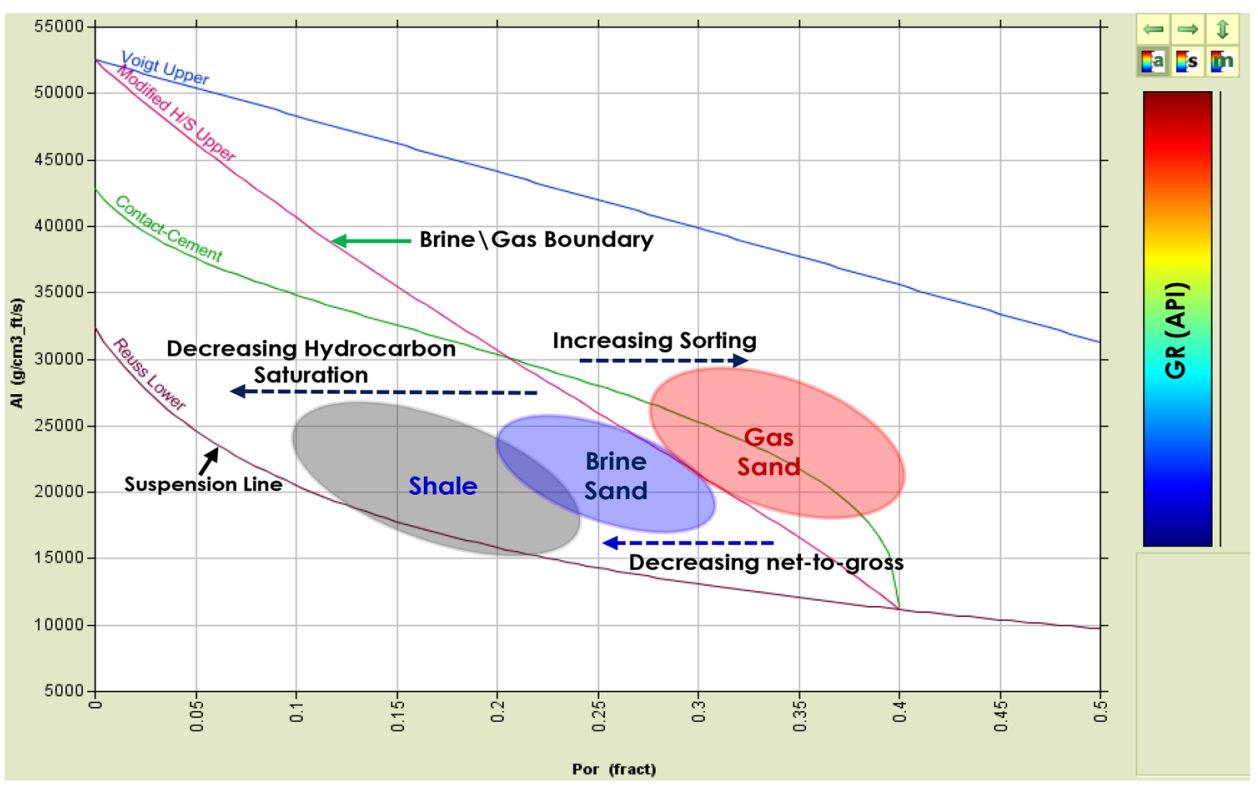

Open Access This article is licensed under a Creative Commons Attribution 4.0 International License, which permits use, sharing, adaptation, distribution and reproduction in any medium or format, as long as you give appropriate credit to the original author(s) and the source, provide a link to the Creative Commons licence, and indicate if changes were made. The images or other third party material in this article are included in the article's Creative Commons licence, unless indicated otherwise in a credit line to the material. If material is not included in the article's Creative Commons licence and your intended use is not permitted by statutory regulation or exceeds the permitted use, you will need to obtain permission directly from the copyright holder. To view a copy of this licence, visit http://creativecommons.org/licenses/by/4.0/.

Publisher's Note Springer Nature remains neutral with regard to jurisdictional claims in published maps and institutional affiliations. 